\title{
Reconstructing Africa's Development in the New Millennium Through NEPAD: Can African Leaders Deliver the Goods?
}

Cyril I. Obi*

\section{Introduction}

This study critically explores the linkages between the post-Cold War 'new' African ruling class its global allies, and the challenge of the continent's development in the new millennium. It takes the form of a critique of the New Partnership for Africa's Development (NEPAD) as the expression of the collective developmental vision of a 'new' generation of African leaders. Beyond this, it teases out the global connection to NEPAD and captures its implication for the development project in Africa in the $21^{\text {st }}$ Century.

This involves a radical understanding of NEPAD as the new strategy of an African ruling elite intent on jump-starting the engine of Africa's development by accepting wholesale the hegemonic global discourses on the neo-liberal market-model of development, and forging a new (but unequal) partnership with the advanced capitalist countries or the G-8 group of industrial powers. By the same logic, it involves an analysis of the problems and prospects of Africa's 'new' leaders successfully re-charting Africa's development through NEPAD, particularly in the face of the further marginalisation of the continent by the forces and process of globalisation, as well as the growing demands within the continent for the dividends of democracy and development. In this regard, it is important to address the fundamental issue of whether the 'new' African leaders can meaningfully engage (rather than bow before) hegemonic transglobal forces in a 'unipolar' moment, to re-negotiate, and transform Africa's subordination in a rapidly globalising and unequal world.

\footnotetext{
* Senior Research Fellow, Nigerian Institute of International Affairs, 13/15 Kofo Abayomi Road, Victoria Island, GPO Box 1727, Lagos, Nigeria.
} 


\section{NEPAD and the African Leadership}

NEPAD symbolises the new thinking of Africa's leadership on development. This is brought out in sharp relief in the opening paragraph of the NEPAD document (2001:1):

This New Partnership for Africa's Development is a pledge by African leaders, based on a common vision and a firm and shared conviction, that they have a pressing duty to eradicate poverty and to place their countries, both individually and collectively, on a path of sustainable growth and development, and at the same time to participate actively in the world economy and body politic. The Programme is anchored on the determination of Africans to extricate themselves and the continent from the malaise of development and exclusion in a globalizing world.

It is clear that African leaders see in NEPAD the vehicle to transit from underdevelopment to development, and from exclusion to inclusion into the mainstream of a rapidly globalising world. The implication of this is that NEPAD is seen as a 'historic' opportunity to take advantage of the 'unipolar' moment to integrate Africa on more generous terms into the charmed circle of capitalist economic globalisation. Determined to swim out of the global backwaters where poverty, conflict, environmental degradation, crisis and disease hold sway, African leaders in the $21^{\text {st }}$ century declare to the world that (NEPAD, 2001:2):

We will determine our own destiny and call on the rest of the world to complement our efforts. There are already signs of progress and hope. Democratic regimes that are committed to the protection of human rights, people centred development and market-oriented economies are on the increase. African peoples have begun to demonstrate their refusal to accept poor economic and political leadership.

This is not just telling the world, but inviting it to support the new initiative of African leaders: "It is a call for a new relationship of partnership between Africa and the international community, especially the highly industrialized countries to overcome the development chasm that has widened over centuries of unequal relations" (NEPAD, 2002:2).

NEPAD is thus located at the conjuncture of an African leadership vision, driven largely by the intention of delivering the goods of 
development to its people, and a particular understanding of the reality of the structure of global power, and how it can ultimately shape the outcome of Africa's quest to develop, based on a redefinition of its relationship with the rest of the world. This much can be gleaned from the NEPAD document and the signposts along its road map.

According to Ohiorhenuan (2002:10), NEPAD's strategic framework is made up of five main elements:

- First is the insistence on African ownership, responsibility and leadership and the building of capacity to play the role.

- Second is the focus on developing a new partnership with the industrialised countries and multilateral organisations on the basis of mutual commitments and obligations.

- Third is the commitment to nurturing an enabling socio-political environment by minimising conflict and promoting democracy and human rights.

- Fourth is the commitment to an enabling economic environment by ensuring macro-economic stability and maintaining transparency and accountability in institutional support mechanisms for the market.

- Fifth is promoting sub-regional and continental economic integration.

In relation to its programme of action, NEPAD hinges upon four broad initiatives: Peace and Security Initiative, Democracy and Political Governance Initiative, Economic and Corporate Governance Initiative, and Sub-regional Approaches to Development. NEPAD activities are coordinated by its Secretariat in South Africa, while its management is led by the Head of States Implementation Committee, the Steering Committee and the 5 task teams (Ohiorhenuan, 2002:11; NEPAD, 2001; http://www.gov.2a/docs/nepad). These NEPAD structures, controlled by the 'original' five or core-NEPAD initiating Heads of state (Nigeria, South Africa, Algeria, Egypt and Senegal), give depth and breath to the vision of African leaders, fashioning programmes and policies for the propagation of the new African developmental initiative, regionally and globally. In this regard, African leaders through NEPAD have promised to deliver on the following developmental goals (NEPAD 2001:11-12): 
- Strengthening mechanisms for conflict prevention, management and resolution at the sub-regional and continental levels, and to ensure that these mechanisms are used to restore and maintain peace;

- Promoting and protecting democracy and human rights in their respective countries and regions, by developing clear standards of accountability, transparency and participatory governance at the national and sub-national levels;

- Restoring and maintaining macro-economic stability, especially by developing appropriate standards and targets for fiscal and monetary policies, and introducing appropriate institutional frameworks to achieve these standards;

- Instituting transparent legal and regulatory frameworks for financial markets and auditing of private companies and the public sector;

- Revitalising and extending the provision of education, technical training and health services, with high priority given to tackling HIV/AIDS, malaria and other communicable diseases;

- Promoting the role of women in social and economic development by reinforcing their capacity in the domains of education and training; by the development of revenue-generating activities through facilitating access to credit, and by assuring their participation in the political and economic life of African countries;

- Building the capacity of states in Africa to set and enforce the legal framework, as well as maintaining law and order;

- Promoting the development of infrastructure, agriculture and its diversification into agro-industries and manufacturing to serve both the domestic and export markets.

Having described in some detail the new vision of African leaders for re-constructing Africa's development in the new millennium, it is necessary to critically examine the strengths and weaknesses of the NEPAD project, and its prospects to deliver development to the masses of the African people.

Since NEPAD was formally launched in Abuja on October 23, 2001, it has drawn a lot of attention from policy makers, politicians, the donor community, scholars, civil society groups and activists. While it has received support and the seal of approval of the leaders of the G-8 Group of Countries, and the Bretton Woods Institutions, 
it has been sharply criticised by civil society groups, scholars and activists in Africa who point out that:

While many of its stated goals may be well intentioned, the development vision and economic measures that it canvasses for the realization of these goals are flawed. As a result, NEPAD will not contribute to addressing the developmental problems mentioned. On the contrary, it will reinforce the hostile external environment and the internal weaknesses that constitute the major obstacles to Africa's development (TWN-Africa, 2002:2).

The following questions are thus pertinent. Is NEPAD really the vision of African leaders? Why did it emerge on the scene at the beginning of the $21^{\text {st }}$ Century, and which forces propel it? What is the global agenda of the 'new' African (democratic) leaders? Does NEPAD advance or subvert the interests and welfare of majority of African? What is to be done to free up the social forces, dynamics and processes so necessary for genuine self-reliant African development beyond the home-grown rhetoric of NEPAD?

In order to provide answers to the foregoing questions and address the concerns of this study, it is divided into four broad sections. The introduction sets out in detail the idea of development as envisioned by NEPAD and the commitment of the African leadership to this new project. It is followed by an analysis of Africa's developmental efforts prior to NEPAD, particularly those from the 1970s onwards. This section which also places NEPAD in historical and global perspective, lays bare its external moorings in spite of the rhetoric of its being a home-grown, African-owned initiative. The third section, which constitutes the analytical fulcrum of the paper, is a critique of NEPAD as a trans-global hegemonic project reflecting Africa's subordination, and the wholesale acceptance by African leaders of the paradigm of their subordination as that of development based on a 'new' partnership with the G-8 countries. The fourth and concluding section seeks answers to the question as to whether African leaders can deliver development through NEPAD in spite of the flawed assumptions and unequal partnership upon which it is erected. In the final analysis, an alternative developmental path based on a popular vision of development rooted in the African people and a participatory framework of democracy is proferred. 


\section{Africa Development and NEPAD in Historical Perspective}

Although NEPAD is very young, it springs from certain historical imperatives which underscore a concern to overcome the crisis of development in which African countries had been immersed in for over three decades. The immediate background however was the failure of IMF/World Bank structural adjustment programmes to arrest Africa's economic and external debt crises. In fact, the adoption of structural adjustment in the 1980s worsened social life and had adverse consequences on the African economies it sought to stabilise in the first instance. This led to widespread protests in 'adjusting' African countries against structural adjustment and its pernicious conditionalities. There is no doubt, that in part, the 'democratic momentum' that swept across the continent in the 1990s was strengthened by anti-structural adjustment protests.

Yet adjustment itself was at the core of the neo-liberal development paradigm of the so-called Washington consensus for which the Bretton Woods Institutions, the World Bank and the International Monetary Fund (IMF), had been well-known. Thus, the failure of structural adjustment in Africa posed very serious problems for the neoliberal discourse of development hinged upon the market model of private sector/export-led growth, free trade, unhindered movement of finance capital, and the expulsion of the state from the economy. Therefore, a frantic search began for an alternative to structural adjustment which had been attacked by the African people for its anti-people, anti-democratic ethos, its external origins, and the fact that it had the impact of further impoverishing the people as a result of its obsession with 'getting the prices right', and the erosion of the welfare gains of the post-colonial state. The 'new' approach to the neo-liberal paradigm of development was based on two planks, first, a shift that included 'getting the politics right' - good governance, accountability, transparency and the rule of law, which fell under the rubric of the new market-based political economy (Abrahamsen, 2000), and secondly, the concern with preventing Africa from going under and collapsing from the sheer weight of its own contradictions - statism, corruption, conflict, failed states and poverty. These also underscored the need for the G-8 to ensure that Africa did not to 
export security threats to the western world (Obi, 2000a). Both planks emphasised the need for Africa to surrender all to the new hegemonic development paradigm of market-led growth.

Thus, there was an effort in post-structural adjustment Africa by the West to throw away the 'adjustment' bathwater, but keep the 'neo-liberal' baby. The essence of structural adjustment was retained in the 'neoliberal baby' which was then re-named, and 'sold' to another generation of African leaders that had risen to power on the crest of the 'democratic' wave, and were equally keen to boost their global and local legitimacy by attempting to lead their people out of the crises of development in which they had been immersed for decades. In the face of the de-legitimisation of the socialist model in global developmental discourse, and the hegemonic profile of the market-led growth paradigm as the homogenising ideology of capitalist globalisation and the Bretton Woods Institutions, African leaders have somehow found themselves caught between a rock and a hard place. On the one hand, they seek development through further integration (on more generous terms) into the globalised capitalist system, while on the other hand they seek to appear as the true representatives of the collective developmental interests and aspirations of Africa in a new century. Yet the popular critique of capitalism and the socially harsh impact of its globalised variant on African countries and peoples poses serious difficulties for the new agenda of the African leaders whose new vision of NEPAD as an African-authored initiative, was largely at the promoting of Western leaders (Adesina, 2002).

It is in the light of the foregoing, the delegitimisation and failings of structural adjustment, and the aspirations of African leaders to discover a new path to development based on past experiences and the promptings of the G-8 countries, that we can explain the background to NEPAD. From an ideological perspective, its claims to being home-grown and African-owned are no more than a reflection of the antics of the Bretton Woods institutions and their local allies in Africa to destroy the nationalist and popular platforms on which anti-structural adjustment protests were organised in the 1980s and 1990s in Africa. The embrace of the macro-economic and macro-political frameworks of the Bretton Woods institutions by African leaders and the domestication of market-led growth policies 
in NEPAD, thus provide ideological justification and legitimacy for a 'new' capitalist 'revolution' as the only path to the reconstruction of Africa's development in the $21^{\text {st }}$ century. It remains to be seen, however, how African leaders are going to pull off this revolution by reinforcing a subordinate partnership with advanced capitalist countries in a rapidly globalising world. Before going further, it would be apposite to examine in closer detail the evolution of NEPAD.

\section{The Evolution of NEPAD:The Historical Background}

At independence in 1960 African countries looked forward to the future with a vision of development based upon state-led growth. As observed elsewhere (Obi, 2000a:39):

These 'developmental states' were guided by the thesis on the modernisation of society through state-led capitalism, welfarism, and an industrialization strategy of import substitution. The principle was that through a trickling down process, the wealth generated by state-led capitalism would transfer wealth to the masses and resolve the problem of poverty.

After two decades of independence, where in most cases, the independence democratic movement had been undermined, or even supplanted, by single party or military rule, the promise of development and 'abundance for all' turned out to be illusory for the majority. Rather than reap the bounty of the harvest of development, these states stagnated in underdevelopment, or even regressed as a result of oppressive leadership, or the uncritical acceptance of Western modernisation/economic models that failed miserably.

It is against this background that the search began in the 1970s for an alternative African model of development. Adedeji (2002b:18), traces this to the 'Revised Framework of Principles for the Implementation of the New International Economic Order in Africa (1975-1977), to the Monrovia Strategy (1979) and culminating in the 1980 Lagos Plan of Action for the economic development of Africa'. In another paper, Adedeji (2002a:35) notes that there were five landmark strategies since the 1980s adopted by African leaders to advance the continent's development. These were: 
1. The Lagos Plan of Action for Economic Development for Africa, 1980-2000 and the Final Act of Lagos (1980).

2. Africa's Priority Programme for Economic Recovery 1986-1990 (APPER), which was later converted into the United Nations Programme of Action for Africa's Economic Recovery and Development (UN-PAAERD) (1986).

3. The African Alternative Framework to Structural Adjustment Programme for socio-economic Recovery and Transformation (AAF-SAP) (1989).

4. The African Charter for Popular Participation for Development (1990).

5. United Nations New Agenda for the Development of Africa in the 1990s (UN-NADAF) (1991).

Most of these efforts by African leaders were premised on African self-reliance and integration, popular participation in development, the centrality of the state to the developmental processes, the removal of inequities in the international economic and trading system, and an African alternative to market-led growth. In its essential form, the African alternative critiqued the very basis on which the Western model of market-led growth was erected. In this same spirit, the Economic Commission for Africa (ECA) in 2000 produced yet another plan for the continent's development called the Compact for African Recovery. Yet, in spite of its indigenous and pan-Africanist slant, the 'five strategies' of the 1980s and 1990s, were eventually sidetracked and abandoned by African leaders by the turn of the century. As Adedeji (2002a:35) argues; these home-grown strategies of African development “... were opposed, undermined and jettisoned by the Bretton Woods institutions and Africans were thus impeded from exercising the basic and fundamental right to make decisions about their future". He notes further, that:

... given their excessive external dependence, their narrow political base and their perennial failure to put their money where their mouth is, the implementation of these plans has suffered from benign neglect. Lacking the resources and the will to soldier on self-reliantly, they abandoned their own strategies, including the two - UN-PAAERD and UN-NADAF - which were crafted jointly with the international community. 
Thus, the abandonment of indigenous models led to the adoption and implementation of exogenous models, particularly those prescribed by the Western Development Merchant System (DMS). According to Adedeji (2002a:36), the DMS provides for economic policies and paradigms which they foisted upon Africa 'regardless of the negative impact of such policies on African economies and politics'. Adedeji citing Kakwenda, also points out, that 'the overarching objective of DMS is for the African canoe to be firmly tied to the North's neoliberal ship on the waters of globalisation'. In this regard, African leadership as a part of a global ruling elite, fully embraces the neoliberal political economy paradigm and its policies which routinely marginalise and impoverish the masses of the African people.

It is however important to note that the African leadership is not so much under the influence of the Bretton Woods Institutions, as it is under the influence of the power behind these institutions - the highly industrialised states of the West - the G-8, the Multinational Corporations and the Donor Community whose power and dominance of the globalised world is of hegemonic proportions.

The issue that then comes to mind, now that it is clear that there were earlier home-grown and African-owned development initiative that engaged the international community, is that of the timing of the drawing up of the NEPAD document. Why did NEPAD emerge on the African scene in the post-Cold war phase of globalisation? Olukoshi (2002c) offers an explanation:

The process leading to the formulation and adoption of NEPAD could, in its remote origins, be traced to the arrival of the post-Apartheid era in African politics and the widespread feeling that with the task of continental liberation from foreign and minority rule having been completed, the next challenge which Africans now needed to face frontally was that of promoting economic development.

Other factors that fuelled the circumstances within which NEPAD emerged, include the growing Afro-pessimism in Western policy, donor and scholarly circles, the low levels of aid to Africa in spite of the end of the Cold War and the increased aid flows to Eastern Europe, and alarm in Africa that the world was fast abandoning the continent to its own fate (Olukoshi, 2002a:88-89; 2002b; 2002c). Other factors include the emergence of a crop of new democratic leaders intent on reversing African fortunes in the $21^{\text {st }}$ century. 
Of specific note, were Thabo Mbeki, an apostle of the African Rennaissance, who succeeded Mandela as President of a postApartheid South Africa, and President Obasanjo (retired Army General and former military head of state) who returned to power in Nigeria - this time via democratic elections in 1999, after a decade and a half of military authoritarianism and political crisis.

The notion of an African rebirth first found early expression in Thabo Mbeki's famous speech in South Africa, in which he called for an African Rennaisance in the $21^{\text {st }}$ century. At that time, as Vice President of the Post-Apartheid South African state Mbeki had declared that, 'those who have eyes to see, let them see the African Rennaissance is upon us' (Mbeki, 1998, 2002a). The notion of the African Rennaissance was to some extent rooted in earlier philosophical discourses on Pan Africanism, Negritude, Ubuntu or Black consciousness (Melba, Cornwall, Gatheka and Wanjala, 2002:5). It was these discourses that influenced the notion of African Rebirth based upon a 'new' model of Pan African development and a pro-active African engagement with the world's powers (Mbeki, 2002b). It is important to note that by 1999 when NEPAD was literarily in the womb, Presidents Mbeki, Bouteflika and Obasanjo chaired the Organisation of African Unity, the Group of 77 countries, and the Non-Aligned Movement (NAM) (Akinrinade, 2002) - all African and Regional bodies that occupied important positions in the evolving post-Cold War order in which globalisation was a major force.

This placed them in a unique position to tap into global and multilateral spaces in pursuit of an agenda for a new Africa in a more sympathetic (pro-Africa) world. It was in this capacity that they "met with G-8 leaders in Okinawa, Japan to discuss the issue of debt relief for developing countries, generally, but African countries in particular" (Adesina, 2002a). This was also in the context where as far back as 1993, Japan (which was the host-country of the G-8 summit 7 years later in 2000), had during the Tokyo International Conference on African Development (TICAD) sought to revive the interest of the international community in Africa (Kawaguchi, 2002:1-2). At this meeting under the rubric of TICAD I, the participants - African countries and development partners - adopted the Tokyo Declaration. According to official Japanese sources under TICAD I (Ministry of Foreign Affairs, Tokyo, 2002): 
- Agreement was reached among African countries and development partners concerning the direction of cooperation for Africa. This agreement provided the guideline for cooperation with Africa.

- The Tokyo Declaration responded to the sense of crisis among African countries that they would be left behind by the international community, due to their economic difficulties and the decline in the international society's interest toward Africa.

TICAD I, was followed by TICAD II in 1998, during which the concepts of 'Ownership' and 'Partnership' were established as the underlying principles of cooperation between the international community and Africa. TICAD III is planned for October 2003 within a period designated in Japan as the "Year of Soaring Cooperation with Africa' (Kawaguchi, 2002:2). In the same regard Adesina (2002c:2) notes that NEPAD was framed within a global development discourse that emphasised partnership between Africa and the international community:

The NEPAD document locates itself within a broad international development debate, while emphasizing local ownership as an African-driven and African focused initiative. NEPAD proceeds on a claim of global consensus in the wake of several multilateral initiatives, such as the UN's New Agenda for the Development of Africa, The Copenhagen Declaration on Social Development, the World Bank-led Strategic Partnership for Africa, the IMF-led Poverty Reduction Strategy Papers and bilateral efforts such as the Tokyo Agenda for Action, and the United States' African Growth Initiative.

Thus, by the time that Presidents Obasanjo, Bouteflika and Mbeki, met with the G-8 leaders in Japan in July 2000, the notions of 'ownership' and 'partnership' has been well integrated into the developmental dialogue between Africa and the developed countries. It is therefore not surprising that the "outcome of the meeting was a demand by the G-8 for a workable plan as the basis of the compact" (Adesina, 2002b:ix). According to Adesina, "after Okinawa, Mbeki was given the responsibility by the troika to develop a workable plan as the G-8 had demanded". This explains why the early drafts of the NEPAD document were "driven by a distinct South African reading of the development problems facing Africa and the prognosis for 
Africa 'extricating itself' out of its development quagmire" (Adesina, 2002b:x). At the World Economic Forum meeting in Davos, it was clear that Mbeki had bought into the notion of a partnership, during his presentation on the Millennium African Renaissance Programme (MAP), which also harped on African ownership of its new developmental direction. This was how the Millennium Partnership for Africa's Recovery Programme (MAP) was drawn up, and subsequently received legitimation through the Organisation of African Unity (OAU). As noted earlier, several scholars have pointed out that the MAP was heavily influenced by Mbeki's project of an African Renaissance (De Waal, 2002; Taylor 2002a; Taylor 2002b; Olukoshi, 2002a; 2002b; 2002c). But it also important that it was also framed within the 'ownership' and 'partnership' paradigm of global cooperation discourse as dictated by the G-8 whose leaders were consulted during the writing of MAP (Nabudere, 2002:51).

The OMEGA plan of President Wade, earlier presented to the Franco-African Summit in Cameroon as a project for "regional infrastructural and educational development", was integrated into the MAP, on the basis of the decision of the May 2001 Conference of Africa's Ministers for Finance, Planning and Economic Development (Akinrinade, 2002). The task of the merger was undertaken by South Africa and Nigeria, and they were later joined by Egypt and Senegal. The third component of NEPAD (the least influential), was the Compact for African Recovery, an Economic Commission for Africa (ECA) development programme which was also merged with MAP in May 2001. At this point, the merged programmes became the New African Initiative (NAI), which was adopted at the July 2001 OAU summit in Lusaka, Zambia, where the Implementation Committee of 15 African Heads of State for the NAI was established (De Waal, 2002:466-467). In October 2001 at a meeting of the NAI Implementation Committee in Abuja, Nigeria, the New African Initiative was renamed the New Partnership of African Development (NEPAD).

Since the adoption of NEPAD, the five initiating presidents Mbeki, Obasanjo, Bouteflika, Wade and Mubarak - have spared no moment in promoting the programme at global and multilateral fora. It has also been promoted in all the Western capitals, the July 2001 Summit of the G-8 in Genoa, at the June 2002 Summit of the G-8 in 
Kananaskis where a G-8 African Action Plan was adopted, and the May/June 2003 Summit of the G-8 in Evian.

From the historical background to NEPAD, it is not difficult to agree with Adedeji (2002b: 3) that “... The NEPAD initiative is set within the context of dismal economic performance by African states both in relative and absolute terms when compared to other regions of the world". Yet it is also easy to observe that NEPAD "did not result from participatory local, national and regional strategies, appropriate to the particular concerns of poor and marginalized African countries" (African Canada Forum, Canadian Council for International Cooperation, 2002). This strongly implies that NEPAD is not a true reflection of the will or interests of African people as they were not consulted in the design or implementation stages. The neglect of the African constituency is on the other hand over-compensated for by the gesturing of African leaders to the G8 countries, global business groups and the donor community, to whom NEPAD in its earliest forms was first presented for their approval and support, before it was presented to the OAU Heads of State Summit in Sirte Libya, in March 2001 (Nabudere, 2002:50).

There is no doubt therefore that NEPAD though 'home-grown' in the sense that it was written by Africans, in Africa it was "not home-based". Rather, it was directed at eliciting more generous terms for Africa's integration into the globalised capitalist system which has over time marginalised Africa, divided the continent, and widened divisions either within each country, or between countries. Such expected advantageous terms of integration are expected to yield greater market access for African goods into global markets, debt forgiveness, mobilisation of resources and support for African development programmes and policies, and attract foreign investments and capital into Africa. NEPAD was thus 'homegrown' only to the extent that it satisfied G-8 demands that African leaders 'voluntarily' take responsibility, framed as 'ownership' for a new 'partnership' for development based on western conditionalities but wrapped in African colours by African leaders.

The courting of the highly industrialised countries has fed into a type of ahistorical treatment of the crises of Africa's development which tends to turn a blind eye to the external moorings of the continent's multiple crises. This results in the imposition by African 
leaders upon themselves of the western conditionalities adapted from the Bretton Woods institutions, without any overt pressures from the G- 8 countries. Of particular note is the acceptance of "the governance programme which the international financial institutions developed within the framework of orthodox structural adjustment", repackaged under purported African 'ownership' (Olukoshi, 2002a: 89).

At this point, it is useful to peep beneath the veil of the African ownership of NEPAD and argue like Olukoshi (2002a: 90), that "ownership rests less in its geographical origin and more in its local anchorage". What this implies is that ownership could be more apparent than real, being a claim of a hegemonic African ruling elite to mask a transnational capitalist project hinged upon the reproduction of capitalist accumulation globally. As such, NEPAD, though owned by a globally aligned faction of the African ruling elite, cannot be said to be owned by the African people. At another level, the adoption of the neoliberal or Washington Consensus paradigm by African leaders divorces NEPAD from its local context, acceptable to Africa's external 'development partners', but alien and exploitative to African people.

The extraversion of NEPAD is brought out in bold relief when one compares its language with that of the World Bank and the IMF. Thus, the appearance of 'good governance', 'transparency', 'accountability', 'anti-corruption', 'trade liberalisation', and 'poverty reduction', all go to underscore the linguistic dimension of NEPAD's extraversion. While this may offer a badge of acceptability for the programme within donor and Western circles whose technical and 'politically-correct' language it speaks, it is doubtful if it would attract the same attention among the majority of Africans on whose backs African leaders would ride the NEPAD horse to the neo-liberal developmental El Dorado.

What the foregoing historical and global perspective shows is that NEPAD is the boldest neo-imperialist African-grown project of development. It quite rightly claims that this is done on the basis of a new partnership based on the support of the international community for an African-owned initiative. Yet it has been shown that although NEPAD may have emanated from Africa, it is not of Africa.

The new terms of partnership are thus defined by the new parameters and conditionalities of capitalist globalisation, the need 
for the Western economies to fully tap Africa as the last frontier of the global economy, and prevent threats emanating from Africa, environmental, health, criminal and terrorist, from coming into the prosperous parts of the world. It is also directed at expanding and reinforcing the hold over African leaders, as their plans appear to be the plea for acceptance for integration into the global mainstream, based on their adoption of 'universal rules of neo-liberal economic reform and democracy' and their willingness to impose and implement these rules on themselves, by themselves and for themselves. Yet the imperatives of African development lie less with what is approved externally, and more with what is done locally, especially in the ways people participate in, shape, and define their own agenda of self-reliant development.

\section{NEPAD, Africa's Leadership and the Trans- Territorialisation of Global Power}

As noted in the earlier section, the African leadership is the key to NEPAD, its conception, vision, construction and implementation. Thus, it is important to understand the African leadership itself, its evolution and how this has played out in the local and international politics of the NEPAD process. Beyond this, it also facilitates the location of the African leadership within a framework of transterritorialised global power, which in turn explains the leverage and constraints on the power of the African ruling elite globally.

Before going further, it is necessary to briefly examine the notion of leadership. Leadership is a social phenomenon based on giving direction, purpose or headship to a group, institution or process. It also refers to a relationship between those leading and those who are led in a particular direction, or to achieve set goals. Cartwright (1983:1) defines leadership as "the ability to obtain non-coerced, voluntary compliance which enables followers to attain goals which they share with the leaders". Yet Olugbade (1987:239), notes that:

A leader establishes the goals, purposes, or objectives of the collectivity, creates the structures through which the purposes of the collectivity are fulfilled, and maintains or enhances those structures. Leaders are supposed to co-ordinate, control, direct, guide or mobilize the efforts of others. 
What comes out clearly, is that leadership does not exist in isolation, or rely ideally on force or deceit. Leadership is often based on trust or a pact between the leader and the led. For while the leader is important for social progress, the followers provide legitimacy for the goals to be attained, as well as the energy and resources for the attainment of such goals. In other words, leadership should reflect the collective aspirations of the people or societies that they lead, and defend their most cherished values and ideals.

In this regard, leadership becomes a social contract between leader and followers. The followers give up some of their 'sovereignties', choose their leaders, and expect such leaders to work for the progress of the society. Thus, leaders bound by the social contract based on the consent of the led, are ultimately accountable to the people, and must consult them and truly represent their collective aspirations and goals.

A look at the history of pre-colonial Africa clearly shows that in the cases of both centralised and decentralised societies, even the most powerful ruler was subject to some extent to some form of control, and did reflect the communal spirit of the people and their collective aspirations (Obi, 2002). One of the implications of the colonial intrusion and the integration of Africa into the global capitalist system was the severance of the link between the people and their leaders. For the colonial state appointed its own African puppets - warrant chiefs and 'traditional' rulers who merely obeyed the master's voice, even though they were often dressed up in the robes and beads of African royalty. By the time the nationalist movement gathered momentum in Africa, those who led the peasants, students and workers to reject colonialism through mass resistance and struggle, were often sidelined or eliminated in favour of those who sought accommodation with the colonial power for the peaceful transfer of authority to indigenes.

Many of these compromises were forged on the backs of an elitepeople coalition. The people, driven by anger at the injustice of colonial exploitation and discrimination, saw in the independence from foreign rule, freedom and hope for a better future that would bring democracy, jobs, development and life more abundant for all. Unfortunately, many of these nationalist coalitions collapsed after independence, when the political elite having captured state power, turned on its erstwhile allies, some on whom were in the opposition, 
arguing that such divisiveness was diversionary, and antithetical to national unity and national development.

Thus, in the name of the nation-building project, the African leadership increasingly alienated itself from its own people, undermined the social contract between the leadership and the led which had under-pinned the nationalist coalition, and divorced itself from the collective aspirations of the people within the first decade of independence. This leadership in the context of the Cold War global politics of the time, as well as its privatisation of the state, which had a monopoly of public resources, became prisoners of power, unable to govern effectively, worse, unable to lead their own people towards a defined goal of social progress. Thus, the apparatus of the single party or the military dictatorship provided these leaders with the means to silence all opposition and repress any dissenting voices to their authoritarianism. Even when these leaders displayed a semblance of gestures towards Pan-Africanism and African unity, they were as divided as ever and could provide no united African front against the forces of neocolonialism and imperialism, which were underdeveloping Africa.

Thus, by the late 1970s many African countries were already immersed in crises, resulting from many years of authoritarian rule, corruption, the collapse of their monocultural economies, wild fluctuations in the global oil markets as well as declining prices for their primary products exports. By the next decade, many of them had been forced to adopt IMF/World Bank economic reform packages or structural adjustment programmes (SAP) to enable them to manage their economic crisis and external debt problems. With the end of the Cold War and the build up of popular protest against the harsh conditionalities and consequences of adjustment, many of Africa's dictatorships came to an inglorious end, and were replaced by multiparty democracies which in many cases threw up new leaders, or forced old leaders to adopt new methods of survival in new multiparty contexts.

While most African countries by the 1990s had become multiparty democracies, complete with constitutions and democratically elected leaders, the process essentially remained one of democracy from above. As Mkandawire (1995; Mkandawire and Soludo, 1999) notes, these democracies merely gave the people the right to vote, but not a 
choice, hence the description, 'choiceless democracies'. These were democracies in which the people were faced by candidates from the same class, operating political frameworks that did not guarantee the participation of the people in governance, nor the protection of their economic, social and political rights. It was thus a democratic leadership as defined by the vote, but in reality by the 'imperfect' democratic transitions that ushered them to power.

The foregoing captures the type of the new 'democratic' leadership that emerged in Africa in the era of neo-liberal globalisation. It was a leadership that not so much reflected the collective aspirations of their poor masses, as it did the broad interests of the hegemonic elite that sought to re-legitimise its rule using the form (and not the content) of democracy that had in the post-Cold War world become the internationally acceptable organising principle for politics. This acceptance of (liberal) democracy, Ake (1997:282), argues is "because it has been trivialized to the point that it is no longer threatening to power elites around the world, who may now enjoy democratic legitimacy without the notorious inconveniences of practising democracy". The African power elite, fully aware of this trivialisation of democracy and no longer feeling threatened by Western demands for democratisation, decided to reinforce its hold onto power, by partnering with the West in de-politicising development and democracy in Africa.

At present, Africa's leadership at the dawn of the $21^{\text {st }}$ century is at the crossroads of a globalising world. As it looks Westwards for succour and acceptance based on a new partnership with the G-8 countries, it may do well to reflect on the words of Mwalimu, Julius Nyerere (2000:19-20), who in 1997 observed that:

Africa South of the Sahara is totally isolated in terms of that configuration of developing power in the world of the $21^{\text {st }}$ Century - on its own. There is no centre of power in whose self-interest it's important to develop Africa, no centre. Not North America, not Japan, not Western Europe. There's no self-interest to bother about Africa south of the Sahara. Africa south of the Sahara is on its own.

He goes further to adjure (Nyerere, 2000:22)

The leadership of the future will have to devise, try to carry out policies of maximum national self-reliance and maximum collective 
self-reliance. They have no choice. Hamna!

It would appear that the dialectics of African leadership have been largely shaped by the mode of integration of the continent into the international capitalist system at the turn of the $19^{\text {th }}$ century, and the continued reproduction of this subordinated integration in the $20^{\text {th }}$ century. The same logic of subordinated integration comes out in sharp relief in the era of post-Cold War neo-liberal globalisation, with African leaders 'indigenising' the conditionalities of integration. Thus, the new generation of African leaders who rode to power on the wave of a huge democratic ferment across the continent, but remain committed to the class interests of the ruling elite and the reproduction of global capitalism, have sought to achieve two things. First, to renew the basis of Africa's integration into a highly globalised world on the basis of a 'new partnership' with the capitalist powers of the Industrial North, based on promises of 'internationally-acceptable conduct' in exchange for more global support for a 'new' Africa. In conformity with the spirit of a hegemonic homogenising project of capitalist globalisation, African leaders enthusiastically signal their surrender to the ineluctable logic of capital, in the expectation that this time they will convince the global powers of their sincerity to comply with the rules laid down by the global powers, and in return, win attention and support for African development.

At another level, African leaders seek to globalise the African cause. Reacting as much to globalisation which has further impoverished the continent, as well as to Afro-pessimism which has also led the West to scale down Africa's rating in its strategic and economic considerations, African leaders, particularly Presidents Mbeki, Obasanjo, Wade, Mubarak and Bouteflika, have sought to forge relations with the West on a new basis that is more advantageous to Africa. In this manner, they too by being integrated into a transglobal elite, seek to make a case for the integration of Africa on better terms into a highly globalised world. As Ian Taylor (2002a: 5) argues in relation to the thesis of the global transnational elite:

Originating in the capitalist core, this transnational elite is increasingly developing linkages with like-minded parties in the South to form a truly global elite. The elites of New Africa may be seen as key representatives of this new phenomenon. 
When it is considered that globalisation apart from being another phase in the global expansion of capital hinged upon transterritorialisation and the strategic role of the unhindered movement of capital across a borderless world, it would be easy to understand why African leaders are keen to be a part of the 'latest game in town'. In spite of Africa's small contribution to global trade, it still has a potential market that can be tapped and has a fast-growing population that the West is keen on keeping within African borders. Thus, at certain levels, the West has a stake in a partnership with Africa, but one that privileges Western interests over African interests, and spins a web of control at the bilateral and multilateral levels to ensure African compliance to Western standards, values, conditionalities, and ultimately, demands, in exchange for 'support'.

From the foregoing, it is not difficult to fathom the connection between Africa's 'new' leadership, the trans-territorialisation of global power and NEPAD as the new blueprint of African integration into the global market economy system. What is ironic about this linkage is that African leaders seek through the reform of their relationship with the West to which they have been historically subordinated, to negotiate Africa's freedom and development. There is no doubt that this calculation though seriously flawed is more about affirming the legitimacy of the 'new' African leadership globally, rather than delivering the power over the development process to their own people. But this only comes out clearly after a critical examination of NEPAD.

\section{NEPAD in Critical Perspective}

As noted earlier, NEPAD, the latest blueprint of African development has elicited both support and sharp criticism in different quarters. It is however important to note that those at whom NEPAD is targeted - the G-8 countries - have given it qualified support. As the first paragraph of the G-8 Africa Action Plan notes:

We, the Heads of State and Government of eight major industrialized democracies and Representatives of the European Union, meeting with African Leaders at Kananaskis, welcome the initiative taken by African states in adopting the New Partnership for Africa's Development (NEPAD), a bold and clear-sighted vision of Africa's 
development. We accept the invitation from African Leaders, extended first at Genoa last July and reaffirmed in the NEPAD, to build a new partnership between the countries of Africa and our own, based on mutual responsibility and respect. The NEPAD provides an historic opportunity to overcome obstacles to development in Africa.

It is very important to draw attention to the basis of G-8 support for NEPAD (G-8, 2002:1):

It is, first and foremost, a pledge by African Leaders to the people of Africa to consolidate democracy and sound economic management, and to promote peace, security and people-centred development. African Leaders have personally directed its creation and implementation. They have formally undertaken to hold each other accountable for its achievement. They have emphasized good governance and human rights as necessary preconditions for Africa's recovery. They focus on investment-driven economic growth and economic governance as the engine of poverty reduction, and on the importance of regional and sub-regional partnerships within Africa.

Yet, in spite of the request for $\$ 64$ billion per year to support African development by African Leaders, the G-8 pledged an increase of only $\$ 12$ billion per year by 2006 , but insisting that:

Each of us will decide, in accordance with our respective priorities and procedures, how we will allocate the additional money we have pledged. Assuming strong African policy commitments, and given recent assistance trends, we believe that in aggregate half or more of our new development assistance could be directed to African nations that govern justly, invest in their own people and promote economic freedom.

The foregoing quote from the G-8 Africa Action Plan already reinforces the argument as to the clearly asymmetrical relations that underpin the African-G-8 NEPAD partnership. It also shows the subordination of the partnership to the notorious conditionalities of structural adjustment, and indeed is an effort to institutionalise this at the bilateral and multilateral levels. It also gives individual G- 8 countries, and the G- 8 as a whole, the leverage to define their priorities and procedures and how much they would give on this basis to a continent whose resources have been plundered over the centuries. Thus, there is no doubt where the real power lies in this partnership, just as it is clear whose values and standards the African 
NEPAD initiative seeks to uphold. As Taylor notes (2002a: 1):

... the new hearing being granted to the New Africa representatives is precisely because the message communicated fits the neoliberal discourse and avoids blaming particular policies or global trade structures for Africa's marginalization but rather, if pushed simply passes off the blame on the mystical notion that is known as globalisation. In addition, the leading elements within the New Africa have gained the North's seal of approval regarding their outward commitment to liberal democracy and market economies, and are held up as models by which the rest of the continent can/should learn from.

Thus, as well-intentioned as NEPAD may appear as a strategy for reconstructing Africa's development in the $21^{\text {st }}$ century, there is a dimension of neo-imperialism to it, which undermines the autonomy and resolve of the 'New Africa leadership' to change the basis of its partnership with the West, and by the same token, develop Africa. In other words, the African leadership seems to be stuck with the mindset that if it 'complies'; the West will 'help' Africa to develop.

Looking at the NEPAD document itself, there are contradictions and some flawed assumptions. These have come out in the critiques made by Olukoshi (2002a, 2002b); Taylor (2002a, 2002b); Mafeje, (2002); Mkandawire, (2002); Moyo, (2002); Africa Canada Forum, (2002); Deng, (2002); Campbell, (2002); Tadasse, (2002); and Adesina, (2002a, 2002b). In order to critique NEPAD in the context of the leadership, attention needs to be focussed on the Democracy and Governance Initiative as articulated by the document. In this regard the works of Olukoshi $(2002 a, 2002 b ; 2002 c)$ are quite instructive. The Democracy and Political Governance Initiative of NEPAD (NEPAD, 2001:17-18), notes "that development is impossible in the absence of true democracy, respect for human rights, peace and good governance. With the New Partnership for Africa's Development (NEPAD), Africa undertakes to respect the global standards of democracy, which core components include political pluralism, allowing for the existence of several political parties and workers' unions fair, open free and democratic elections periodically organized to enable the populace choose their leaders freely". This clearly show the commitment of African leaders to liberal democracy in the electoral, 'choiceless' sense. Yet, as Mafeje 
(2002:81) argues, "It is obvious that in the modern world liberal democracy cannot satisfy the emerging political and economic demands that are a result of new forms of social awareness".

Olukoshi (2002a: 5) points out in his critique of the initiative, that it is couched in a framework that is "lacking in the kind of basic social anchor that can ensure that the democracy and governance proposals that are made are moved from the realm of the pro forma and technocratic to the arena of the political as a living experience marked by contestations and negotiations among the bearers of competing interests". Beyond the lack of popular participation in ensuring that the initiative reflects human-developmental, rather than technocratic and managerial priorities, there is no clear role for the people in the politics of NEPAD. Taking on the democracy and governance initiative of NEPAD headlong, Olukoshi (2002a: 90) doubts if it represents or seeks to advance the cause of popular political forces in Africa:

... the democracy and governance initiative of the NEPAD raises more questions than it answers and, on a more critical examination, seems designed more to pander to a donor audience than responding to, or representing the concerns of the domestic forces in the vanguard of the struggle for the reform of the political space and developmental agenda.

Since it 'panders' to the donors, and by implication the G8 countries, NEPAD is clearly not about the transformation of the unequal partnership with the West, nor is it about the radical restructuring of the unjust state-society relations in Africa. As such, it appears merely to fuel what Ake $(1992 ; 2000 ; 2001)$ described as the "democratization of the disempowerment of the African people" (Olukoshi, 2002a: 93; 2002c). This is given credence by the lack of a framework of civic engagement in the NEPAD document, as well as the non-consultation of civil society in Africa by African leaders in drawing up, and implementing, the NEPAD document. Thus, irrespective of the commitment to the virtues of good governance, accountability, transparency and poverty reduction, it is clear that the kind of democracy being promoted by NEPAD is choiceless and elitist, and does not take on board the concerns, interests and participation of the people on whose behalf the NEPAD document was drawn up. 
In the same regard, while the NEPAD document makes African leaders clearly accountable to their international partners, on the basis of global standards and values, it is difficult to see how these same African leaders are going to be accountable to their own citizens for the implementation of NEPAD. It would appear that NEPAD's focus on accountability is one-sided, in favour of African leaders and their global partners.

Another aspect of NEPAD that links the African leadership to the issue of accountability and governance is the African Peer Review (APR) mechanism or code of conduct. The African Peer Review mechanism provides for African leaders to voluntarily submit themselves periodically to the test, and be accountable to each other for their commitment to good governance, respect for human rights and the rule of law as well as economic and corporate governance. The APR mechanism provides for best practices as regards specified codes and standards for political and corporate governance, complete with an in-built reward and sanction system for all those who sign up. It is perhaps a novel dimension to Africa's development strategy. According to De Waal (2002:471):

The APR mechanism broadly echoes the OECD peer review mechanism, which is regarded as a successful means of identifying and promoting appropriate practices. The rationale for the APR is that Africa should move away from donor-imposed conditionalities, which have been found ineffective, inefficient and burdensome, towards mutual accountability among development partners towards desired outcomes (specifically poverty reduction).

The criticisms that could be levelled against the APR are similar to those mentioned earlier. While one agrees with De Waal on the rather difficult task of the APR, it is more pertinent that Olukoshi (2002c) argues that its mere existence is not enough to guarantee the integrity of the review process.

It is also instructive that he draws attention to the danger of the NEPAD APR mechanism evolving into "the route by which some of the conditionalities of the adjustment years are locked into the fabric of African economy and politics". In this regard, the contradictions of the APR in its application, and the risks inherent in it are illustrated in the case of the recent Zimbabwe crisis (Taylor 2002b: 404-408). 
Thus, the APR's being an incentive to external donors to support African leaders who practice good governance is a much more complicated issue than it appears to be on the surface and may yet become a noose around the necks of some African leaders that can be tightened at will by the donor community.

The point has been made also about NEPAD's external dependence. Nowhere is this more pronounced as in the area of its Resource Mobilisation Strategy (Moyo, 2002:183-208). Africa, although rated as the poorest continent in the world, is still a net exporter of capital and can mobilise its own resources. But the framers of NEPAD still look up to the Industrial North for aid, Direct Foreign Investments and trade access. As Moyo (2002:207), notes:

NEPAD appears to ignore the ideological dimensions of external funding and a market- based model of development in a harsh globalised environment. Despite the failures of aid and transnational capital in promoting pro-poor development in Africa, the overriding concern in NEPAD appears to be the access to capital rather than any moral, social and political considerations.

In a global context where the rate of FDI to Africa is declining and largely limited to a few countries on the continent (based on mineral exports and market size), NEPAD's extraversion in seeking resources merely amplifies the obsession with the neoliberal macro-economic framework and the lack of popular roots.

Another aspect that has been sharply criticised about the NEPAD document is its very scant regard for women and gender issues. In this regard (Tadesse, 2002:275), notes that:

A good governance discourse that is based on a procedural conception of democracy conceived as separate and apart from socio-economic rights and structures - as does NEPAD - has extremely limited transformatory potential for a new and gender-just Africa.

This is against the background of the marginalisation of women in Africa from the structures and the processes of governance and development in the continent. This tends to frame the African leadership in the context of a continental-global patriarchy, but more fundamentally, fails to represent the interests of the one half of the African populace that bears the brunt of the crisis of development in which the continent has been immersed in for over three decades. 


\section{Conclusion: Can African Leaders Deliver the Goods?}

From the foregoing, it is clear that based on NEPAD as currently constituted, African leaders will not only fail to deliver the goods of development to the African people, but will reinforce the structures of external dependence and deepen the underdevelopment of Africa in a globalised world.

In the first instance, African leaders are demanding reform and incorporation based on the same terms and values with which global power has subordinated Africa, while side-stepping the real issues. The Africa-Canada Forum (2002), identifies two such issues as "the reform of global trade and investment regimes, and ensuring effective participation, transparency and fairness in the governance of multilateral institutions".

The most critical issue that is side-stepped by NEPAD is the building of a participatory relationship between African leaders and the citizens of their countries, in ways that transfer real power to the people, and grond policies and programmes upon consultation with, and the consent, of their citizens. It is a 'blind spot' that undermines the legitimacy and workability of NEPAD as the African leaders' blueprint for the reconstruction of the continent's development in the $21^{\text {st }}$ century.

If African leaders adopted an elaborate agenda such as NEPAD, why did they do so in the face of its contradictions and flaws, and without consulting their own people? There are several positions on this question, but only two will be reflected upon here. The first is from Adedeji, and the second from Taylor. According to Adedeji (2002a: 43):

There is always a childlike naivety among African leaders and policy makers that rhetoric and reality are the same and that claiming ownership is tantamount to having ownership. It is the Africans who are claiming they are forging a partnership. The other side will no doubt continue to see it as a donor-recipient relationship.

What then explains the 'naivete' of Africa's new leaders? Adedeji himself provides a hint when he describes NEPAD as a "feudoimperial partnership" (Adedeji, 2002a: 44), between the strong (G-8) and the weak (Africa). What cannot be denied is that African leaders as a faction of a trans-global elite are responding to globalisation 
and the new terms of incorporation and integration. This suggests that the leaders are not that naive but are consciously (or is it subconsciously?) promoting an agenda that will benefit them as a fraction of global capital as well as their global partners.

For his part, Taylor (2002a: 22) reiterates the call for a radical interrogation of NEPAD which as presently constituted will only benefit the few:

African-based initiatives are vitally needed, but it seems clear that what is emerging is a nascent reformism, emanating from key elites in the developing world, that far from ushering in a Twenty-first Century NIEO, remains rooted in an orthodox discourse that benefits but a small elite.

The foregoing issues clearly show that NEPAD in its current form cannot deliver the goods. This immediately raises the challenge of what is to be done. It is clear that as far as the issues of the African Initiative for development and engagement with the international community are concerned, African leaders would need to seek the mandate of the African people. Ownership of the African development project must not begin and end with African Heads of State. NEPAD itself would have to be subjected to a transformational critique directed at placing it under the power of the people. For just as Adedeji (2002b: 21), argues:

Until NEPAD becomes owned by the people of Africa, its civil society and grassroots, the initiative will not take off at the national level. And without taking off at the national level, the plan is as dead as a dodo.

Yet the people of Africa cannot own NEPAD if they remain constrained by the 'choiceless democracies' that hold them captive. There is therefore a need to deepen the content of the democratic process in Africa by placing the people and their participation in the political process at the centre of democratic practices.

At another level, there is also the need to transform the character of the state in Africa as well as the post-colonial mode of accumulation. The new democratic African State in the $21^{\text {st }}$ century must be central to the processes of development in the popular sense of the word. The African developmental state would hopefully represent a solid social basis for Africa's engagement with the world, and 
strengthen its demands for a new and equitable international order. As Mkandawire and Soludo (1999:133) correctly suggest:

What African does need is a system of democratic governance in which political actors have the space to freely and openly debate, negotiate, and design an economic reform package that is integral to the construction of a new social contract for ushering Africa into the $21^{\text {st }}$ century.

It is important that the interrogation of NEPAD by African scholars, civil society activists and people remains an ongoing counterhegemonic project. For without the imperial moorings and internal contradictions being laid bare, the possibilities for the transformation of the African developmental project would become even more complicated, protracted, and unproductive. Beyond this, the popular critique of NEPAD would enrich the process of providing more viable alternatives for African development.

In the final analysis, Africa's development in the $21^{\text {st }}$ century can only be on the basis of self-reliant development, popular democracy, unity and regional integration. The forces that have historically subordinated and exploited Africa for their own benefit are not likely to change their ways in the era of globalisation where the competition for markets and profits is intensely ruthless. The starting point perhaps is for Africa's leaders to interrogate, rather than embrace, globalisation's neoliberal discourses, and become dialectically a counter-elite, siding with the African people against the hegemonic trans-global elite that seeks, through new rules to keep Africa in its subordinated position for yet another century.

\section{References}

Abrahamsen, R. 2000. Disciplining Democracy: Development Discourse and Good Governance in Africa, London, New York, Zed Books.

Adesina, J. 2002a. 'Development and the Challenge of Poverty: NEPAD, post-Washington Consensus and Beyond', Paper presented at the CODESRIA-TWN-Africa Conference on Africa and the Development Challenges of the New Millennium, La Palm Royal Beach Hotel, Accra, Ghana, April 23-26.

Adesina, J. 2002b. 'NEPAD and the Challenge of Africa's Development: 
towards the political economy of a discourse', www.sarpn.org.29. Adesina, J. 2002c. 'Development and the Challenge of Poverty: NEPAD, Post-Washington Consensus and Beyond', CUTS/ARC Policy Briefs, No. 2.

Adedeji, A. 2002a. 'From Lagos Plan of Action to the New Partnership for African Development and from the Final Act of Lagos to the Constitutive Act: Wither Africa?', in Peter Anyang' Nyong'o, Aseghedech Ghirmazion, Davinda Lamba (eds.), New Partnership for Africa's Development: A New Path?, Nairobi, Heinrich Boll Foundation. Adedeji, A. 2002b. 'NEPAD: A View from the African Trenches', Keynote Address, International Peace Academy Workshop, July.

Adesida, O; and A. Oteh, 2001. 'Africa: Visions of the Future', in, O. Adesida and A. Oteh (eds.), African Voices, African Visions, Uppsala, Nordiska Afrikainstitutet.

Africa-Canada Forum, Canadian Council for International Co-operation. 2002. 'The New Partnership for African Development: A Commentary', April.

Ake, C. 2001. Democracy and Development in Africa, Ibadan, Spectrum Books (for African Centre for Democratic Governance).

Ake, C. 2000. The Feasibility of Democracy in Africa, Dakar, CODESRIA Books.

Ake, C. 1997. 'Dangerous liaisons: the interface of globalization and democracy', in Axel Hadenius (ed.), Democracy's Victory and crisis, Uppsala University, Cambridge University Press.

Ake, C. 1992. 'Devaluing Democracy', Journal of Democracy, Vol. 3, No. 3.

Akinrinade. S. 2002.. 'NEPAD: the New Partnership for Africa's Development', The Conflict, Security and Development Group Bulletin, Issue No. 15.

Amuwo, K. 2002. 'Globalisation, NEPAD and the Governance Question in Africa', Africa Studies Quarterly, vol. 6, Issue 3.

Campell, H. 2002. 'The New African Initiative: Peace, Justice and Reparations or the Rekindling of the Human Spirit', in, Peter Anyang' Nyong'o, Aseghedech Ghirmazion, Davinda Lamba (eds.), New Partnership for Africa's Development: A New Path?, Nairobi, Heinrich Boll Foundation.

CODESRIA-TWN-AFRICA. 2002. 'Communique adopted at the end of the CODESRIA-TWN-AFRICA Conference on Africa's Development 
Challenges of the New Millennium', Accra, April 23-26.

Cartwright, J. 1983. Political Leadership in Africa, London, Canberra, New York, Croom Helm, St. Martins Press.

De Waal, A. 2000. 'What's new in the New Partnership for Africa's Development?', International Affairs, 78, 3.

Deng, L. 2002. 'A Reflection Paper on the Sectoral Priorities of NEPAD', in Peter Anyang' Nyong'o, Aseghedech Ghirmazion, Davinda Lamba (eds.), New Partnership for Africa's Development: A New Path?,Nairobi, Heinrich Boll Foundation.

Diop, A. 2001. 'New Partnership for African Development', Africa Quarterly, Vol. 41, No. 4.

Ezereonwu, J. 2002. 'Canadian Premier Promises G-8 Assistance', The Guardian (Lagos), April 7.

G-8. 2002. 'G-8 Africa Action Plan'. Document from the G-8 Summit in Kananaskis, Canada, June 26-27, www.g8.gc.calkan-docs/afractione.asp.

Gelb, S. 2002. 'The New Partnership for Africa's Development (NEPAD):

a brief overview', The Edge Institute, Braamfontein, South Africa.

http://www.ipacademy.org/Programs/nepad.htm. 'NEPAD: African Initiative, New Partnership'.

International Peace Academy. 2002. 'NEPAD: African Initiative, New Partnership', Workshop Report, New York: IPA, July 16.

Kawaguchi, Y. 2002. Policy Speech by Minister for Foreign Affairs, Japan, at the United Nations Conference Centre, Addis Ababa.

Kempe, R. 2002. 'rom Crisis to Renewal: Towards a Successful Implementation of the New Partnership for Africa's Development', African Affairs (101).

Khor, M. 2002. ' Perspective on Globalization and its Implications for Developing Countries', Paper presented at the CODESRIA-TWNAFRICA Conference on Africa and the Development Challenges of the New Millennium, La Palm Royal Beach Hotel, Accra, Ghana, April 2326.

Mafeje, A. 2002. 'emocratic Governance and New Democracy in Africa: Agenda for the Future', in Peter Anyang' Nyong'o, Aseghedech Ghirmazion, Davinda Lamba (eds.), New Partnership for Africa's Development: A New Path?, Nairobi, Heinrich Boll Foundation. Mbeki, T. 2002a. 'Africa's Time has come', News Africa, January 14. Mbeki, T. 2002b. 'Democracy and Renaissance in Africa: In search of an 
Enduring Pax Africana', NIIA Public Lecture, Abuja.

Mbeki, T. 1998. Africa: The Time Has Come, Cape Town and Johannesburg, Tafelberg Publishers and Mafube Publishers.

Melber, H., R. Cornwall, J. Gatheka and S. Wanjala. 2002.' The New Partnership for African Development (NEPAD) - African Perspectives', Uppsala, NAI Discussion Paper, No. 16.

Ministry of Foreign Affairs, Tokyo. 2002. 'The Philosophy of Japan's Policy towards Africa', Mimeograph.

Mkandawire, T. 2002. 'Financing of NEPAD', in Peter Anyang' Nyong'o, Aseghedech, op cit.

Mkandawire, T. 1995. 'Fiscal Structure, State Contraction and Political Responses in Africa', in Mkandawire, T., and A. Olukoshi (eds.), Between Liberalisation and Oppression: The Politics of Structural Adjustment in Africa, Dakar, CODESRIA Books.

Mkandawire, T., and C. Soludo. 1999. OUR CONTINENT, OUR FUTURE: African Perspectives on Structural Adjustment, Dakar and Trenton, CODESRIA and Africa World Press.

Moyo, T. 2002. 'The Resource Mobilization Strategy (RMS) of the New Partnership for Africa's Development (NEPAD): A Critical Appraisal', in Peter Anyang' Nyong'o, Aseghedech Ghirmazion, Davinda Lamba (eds.), New Partnership for Africa's Development: A New Path?, Nairobi, Heinrich Boll Foundation, 2002.

Nabudere, D. 2002. 'NEPAD: Historical background and its prospects', in, Peter Anyang' Nyong'o, Aseghedech Ghirmazion, Davinda Lamba (eds.), New Partnership for Africa's Development: A New Path, Nairobi, Heinrich Boll Foundation.

Ngwane, T. 2002. 'A new partnership for Africa's development or just more Washington-friendly economics', World Development Movement in Action, Summer.

Nyerere, J. 2000. 'Reflections', in H. Othman (ed.), Reflections on Leadership in Africa: Forty Years After Independence, Brussels, VUB Press.

Obi, C. 2002. Leadership in Local Communities in Historical perspective: Pre-Colonial and Colonial Nigeria, Lagos, CSSR and D.

Obi, C. 2000a. 'Trends and Prospects of Civil Society Empowerment for Poverty Reduction in Sub-Saharan Africa', in CODESRIA and UNDP, Annual Report: Civil Society for Poverty Reduction in Sub-Saharan Africa, Dakar, CODESRIA and UNDP. 
Obi, C. 2000b. 'Globalized Images of Environmental Security in Africa', Review of African Political Economy, No. 83.

Ohiorhenuan, J. 2002. 'NEPAD and the Dialectics of African Underdevelopment', NEW AGENDA: South African Journal of Social and Economic Policy, Issue 7.

Olugbade, K. 1987. 'Leadership and the Problem of Ideology in Nigeria', in S. Olugbemi (ed.), Alternative Political Future, Lagos, IPSA.

Olukoshi, A. 2002a. 'Governing the African Political Space for Sustainable Development: A Reflection on NEPAD', in Peter Anyang' Nyong'o, Aseghedech Ghirmazion, Davinda Lamba (eds.), New Partnership for Africa's Development: A New Path?, Nairobi, Heinrich Boll Foundation.

Olukoshi, A. 2002b. 'Governing the African Development Process: The Challenge of the New Partnership for Africa's Development', Occasional Paper, Centre of African Studies, University of Copenhagen.

Olukoshi, A. 2002c. 'Governing the African Developmental Process: The Challenge of the New Partnership for Africa's Development (NEPAD)', Public Lecture Delivered at the Nigerian Institute of International Affairs, Lagos, Nigeria, Tuesday, July 9.

Olukoshi, A. 1998. The Elusive Prince of Denmark: Structural Adjustment and the Crisis of Governance in Africa, Nordiska Afrikainstitutet, Research report, no. 104.

Onimode, B. 2000. Africa in the World of the $21^{\text {st }}$ Century, Ibadan, Ibadan University Press.

Tadesse, Z. 2002. 'In search of Gender Justice: Lessons from the Past and Unravelling the "New" in NEPAD', in Peter Anyang' Nyong'o, Aseghedech Ghirmazion, Davinda Lamba (eds.), New Partnership for Africa's Development: A New Path?,Nairobi, Heinrich Boll Foundation.

Tandon, Y. 2002. 'Will NEPAD Prove Another False Start for Africa?', The East African (Nairobi), July 1.

Taylor, I. 2002a. 'The New Partnership for African Development and Global Political Economy: Towards the African Century or another False Start?', Paper presented at the CODESRIA-TWN-Africa Conference on Africa and Development in the New Millennium, La Palm Royal Beach Hotel, Accra, Ghana, April 23-26.

Taylor, I. 2002b. 'Commentary, The New Partnership for Africa's Development and the Zimbabwe Elections: Implications and Prospects 
for the Future', African Affairs, 101.

Taylor, I., and P. Nel. 2002. 'Getting the rhetoric right, getting the strategy wrong: "New Africa", globalization and the confines of elite reformism', Third World Quarterly, 21, 1.

The NEPAD document . 2001. October 21. 